\title{
Pikas and People: Human-Pika (Ochotona) interaction in the Himalaya of Nepal
}

\author{
NARAYAN PRASAD KOJU ${ }^{1,2, \boldsymbol{y}}$, MUKESH KUMAR CHALISE ${ }^{3,4}$, RANDALL C. KYES ${ }^{2,5}$ \\ ${ }^{1}$ Center for Post Graduate Studies, Nepal Engineering College, Pokhara University. Bhaktapur Road, Changunarayan 44801, Nepal. \\ Tel.: +97-71-5221006, `email: npkoju.2003@gmail.com \\ ${ }^{2}$ Department of Psychology, University of Washington. Guthrie Hall (GTH), 119A 98195-1525, Seattle, WA 98105, USA \\ ${ }^{3}$ Nepal Biodiversity Research Society. Kadaghari 13, Kathmandu 44600, Nepal \\ ${ }^{4}$ Central Department of Zoology, Tribhuvan University. M7MP+5WQ, Kirtipur 44600, Nepal \\ ${ }^{5}$ Departments of Global Health and Anthropology, Center for Global Field Study, Washington National Primate Research Center, University of \\ Washington. 3018 Western Ave, Seattle, WA 98121, USA
}

Manuscript received: 13 August 2021. Revision accepted: 27 October 2021.

\begin{abstract}
Koju NP, Chalise MK, Kyes RC. 2021. Pikas and People: Human-Pika (Ochotona) interaction in the Himalaya of Nepal. Biodiversitas 22: 5085-5091. This study examined human-pika (Ochotona) interaction in two protected areas of Nepal: Lamtang National Park (LNP) and Api Nampa Conservation Area (ACNA). We conducted the study between 2012 and 2017 and employed a combination of three qualitative sampling methods: observation of behavior (both humans and pikas), practices, and rituals of the local residents, pilgrims, tourists, and Yarsagumba (Ophiocordyceps sinesis) collectors; collection of folk stories; and focus group discussions with local residents to investigate the nature of human-pika interaction. Based on the collective data, three general themes relating to human-pika interaction emerged: 1) the perception of pikas as a respected entity; 2) effects of anthropogenic pollution on pikas, and 3) pikas as a traditional medicine. In LNP, the pika was respected as symbol of the Buddhist monk 'Lama'. In contrast, at ANCA, the dried meat of pika was used by local people for traditional medicine. At both locations, there is an increasing human presence resulting in increased anthropogenic pollution. This, in turn, may present a potential risk to the pikas over the long term. Further investigation is needed to address the effects of anthropogenic activities on the pika and to ensure the health and viability of the pika population.
\end{abstract}

Keywords: Anthropogenic pressure, Ochotona, pika, pollution, traditional medicine

\section{INTRODUCTION}

The human-animal relationship has an honored history and deep sense of reverence. In recent years, this relationship (particularly involving wildlife) has become the focus study and concern, with an increasing sense of urgency. Shanklin (1985) described human and animal interaction as one of the most important factors in human evolution. Animals have served multiple human needs as friend, food, commodities and the embodiment of nature (Mullin 1999). At the same time, for many animals, their very survival is now in question, due in large part to anthropogenic pressures (Phair et al. 2020). Therefore, it is essential that we broaden our assessment and understanding of this unique relationship to ensure the conservation of our wildlife and the healthy coexistence between humans and animals.

Nepal is a highly diverse country in culture and ethnicity (Bista 1972; Giri 2020). All the cultures have a close connection with animals and their own ethical values and respect for nature. In the foothills and Himalaya of Nepal, Buddhism and Hinduism are practiced. Both religions have a deep respect for animals. In Hinduism, many of the animals are believed to serve as a means of transport for their god and goddess. For the Buddhists, killing of animals is prohibited and kindness and respect for animals is the honored practice.
One animal in Nepal that has an interesting, yet little studied, relationship with the people is the pika (Ochotona spp) (Figure 1). Pikas are small mammals that inhabit the forests and rocky talus alpine areas of the Himalaya (Kawamichi 1968; Kawamichi 1971; Smith et al. 1990; Koju et al. 2015; Koju et al. 2017; Lissovsky et al. 2019). Changing temperature and acute cold stress are potential threat to pikas in Himalaya (Beever et al. 2011; Smith 2020; Koju et al. 2021). Pikas have a body mass ranging from $180 \mathrm{~g}$ to $220 \mathrm{~g}$ (Abe 1971; Smith et al. 1990) with a body length from $150-200 \mathrm{~mm}$, and are found at elevations ranging between 2800 masl to 5200 masl (Ellerman and Morrison-Scott 1951; Fedosenko 1974; Formozov 1981; Tak and Lamba 1985; Jnawali et al. 2011; Bhattacharyya et al. 2013).

The pika habitat in Nepal often includes scenic areas that serve as tourist trekking sites and locations of pilgrimage for religious people. Additionally, collection of non-timber forest products such as the caterpillar fungus known as 'Yarsagumba' (Ophiocordyceps sinesis) and other valuable herbs is increasing in these Himalayan areas. During rainy season, more than 35,000 people (mostly local residents) stay in the mountains for a couple months collecting Yarsagumba and grazing their livestock (Karki et al. 2020; Sing et al. 2020). 


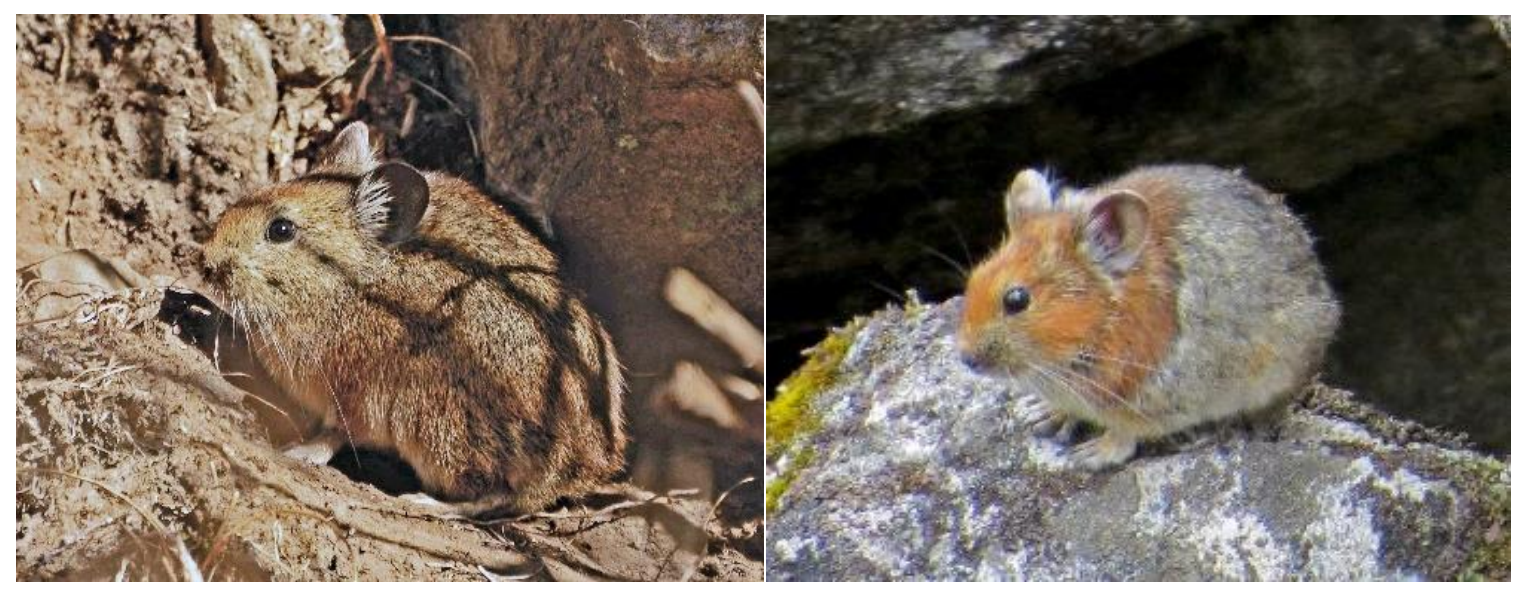

Figure 1. A. A Royle's pika (Ochotona roylii) in Lamtang National Park, Nepal. (Photo by: R.C. Kyes, March 2014); B. A Royle's pika (Ochotona roylii) in Api Nampa Conservation Area, Nepal (Photo by: N.P. Koju, June 2014). Note the coat color/pelage which is in transition from the winter to summer season

The effects from the increasing human presence and their livestock on the local biodiversity in these areas, such as pikas, is largely unexplored. The objective of this study was to examine human-pika interaction in two areas of Nepal that experience many of the human-related activities noted above: Lamtang (formerly Langtang) National Park (LNP) and the Api Nampa Conservation Area (ANCA). Two species of pikas have been documented in LNP: Ochotona roylii (formerly $O$. roylei) and $O$ macrotis; only O. roylii has been observed in ANCA (Kawamichi 1968; Thapa et al. 2011; Koju et al. 2012; Koju and Chalise 2013; Koju et al. 2013; Koju et al. 2017; Lissovsky et al. 2019).

\section{MATERIALS AND METHODS}

Lamtang National Park (LNP) in the central Himalaya, and Api Nampa Conservation Area (ANCA) in the far western Himalaya of Nepal (Figure 2) were visited multiple times between 2012 to 2017 as part of a larger study assessing pika behavior, abundance, and genetics (see, Koju and Chalise 2013; Koju et al. 2017). We spent a total of 16 weeks in LNP over six field periods between July 2012 and January 2017. In ANCA, we spent a total of 5 weeks over three field periods between May 2013 and November 2014.

In order to assess the nature and extent of human-pika interaction at these sites, we employed a variety of qualitative sampling methods (described below), including observation of the behavior, practices and rituals of the local residents, pilgrims, tourists, and Yarsagumba ( $O$. sinesis) collectors; collection of folk stories; and focus group discussions with local residents.

\section{Study sites}

Lamtang National Park (LNP)

LNP was established in 1976 and is the second largest National Park of Nepal located at $28^{\circ} 5^{\prime}$ to $28^{\circ} 22^{\prime}$ North Latitude $85^{\circ} 21^{\prime}$ to $85^{\circ} 42^{\prime}$ East Latitude with an area of $1,710 \mathrm{~km}^{2}$. Sherpa and Tamang represent the major ethnic communities of LNP, with Buddhism practiced by the majority of the population. About 4,500 people live within the park boundary, and many more depend on the park's resources for daily survival and livelihood, such as firewood, timber and tourism (Stevens 1996; Chapagain 2015). The Nepali army maintains several security posts around the park which also help to regulate illegal activities. Human settlements have existed in Lamtang valley for more than 700 years (Stevens 2014). In April 2015, Langtang Village was completely wiped away by a massive avalanche of snow, ice, and rocks triggered by an earthquake that devasted many locations in Nepal (Cadwalladr 2015). Much of the devastated area has now been rebuilt and experiencing increased development. LNP is a popular trekking site receiving more than 4,000 foreign tourists every year. Additionally, more than 8,000 religious pilgrims visit the park during the summer season (Mishra 2011).

\section{Api Nampa Conservation Area (ANCA)}

ANCA was established in 2010 to conserve the natural beauty and ecosystem of this remote, far western and northernmost frontier of Nepal that adjoins India to the west and China to the north. ANCA is located between $29^{\circ}$ $30^{\prime}$ to $30^{\circ} 15^{\prime}$ North Latitude and $80^{\circ} 22^{\prime}$ to $81^{\circ} 09^{\prime}$ East Longitude and is characterized by an ecologically diverged region of Nepal. ANCA occupies $1,903 \mathrm{~km}^{2}$ of the Darchula district. Six villages (Rural Municipalities) with a total population of 69,658 residents lies within ACNA (Ministry of Local Development 2017). Bhramins and Chhetri represent the primary ethnic groups inhabiting this area. Given ACNAs remote location, there is currently no tourism in the area. Further, there are no military security posts located in ANCA. The climate of ANCA varies widely from sub-tropical to alpine. In the north, most of the area remains under snow throughout the year, due to its alpine climate. Only one species of pika has been documented to inhabit ANCA, namely $O$. roylii, and it has been observed at elevations from 2800 masl and above (Koju and Chalise 2013). 


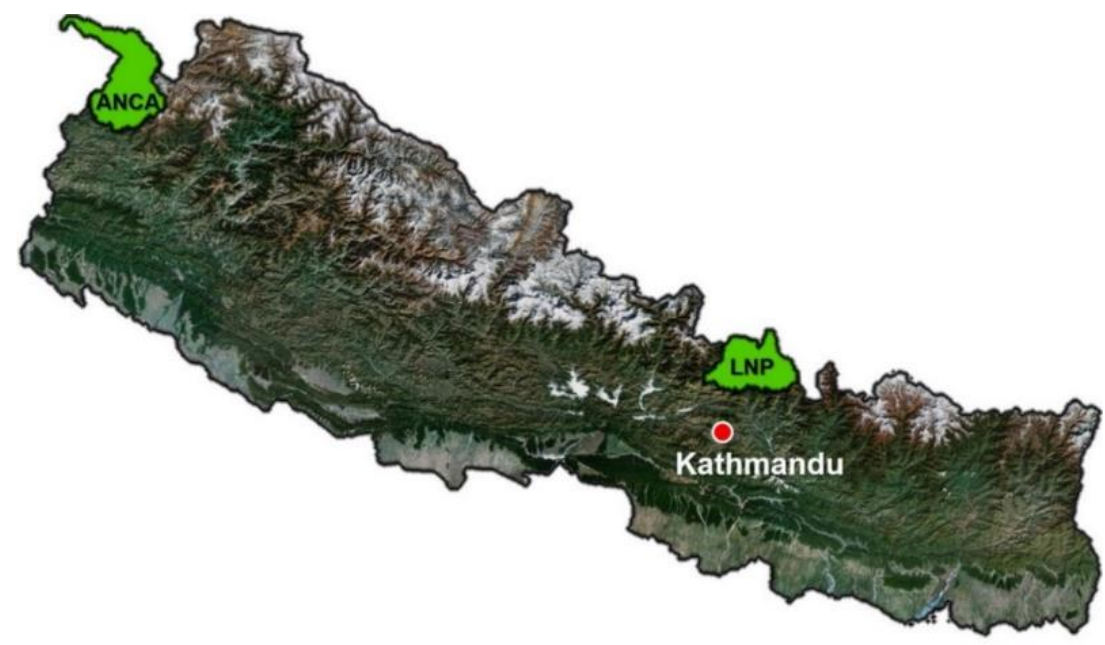

Figure 2. Location of the pika study sites (shaded in green) in Nepal: Lamtang National Park (LNP) and Api Nampa Conservation Area (ANCA). Map adapted from the Department of National Parks and Wildlife Conservation (DNPWC 2020) and Google Maps

\section{Qualitative data collection}

We employed a combination of three commonly used qualitative sampling methods to investigate the nature of human-pika interaction in LNP and ANCA, including: observations of both human and pika behavior, interviews, and focus group discussions (Mack et al. 2005). Behavioral activities of the local people, pilgrims, tourists, etc. as well as the pikas were recorded ad libitum to help document any observed interaction or associated influence from human presence. We (NPK and RCK in Lamtang and NPK and MKC in ACNA) also documented local folk stories, beliefs, anecdotal accounts from the local people relating to pikas. Finally, we conducted a total of four focus group discussions (FGD), two in LNP and two in ANCA. LNP participants included local Buddhist monks or Lamas living in the Gumba ( $\mathrm{n}=8$ people, first group) and local hotel owners ( $\mathrm{n}=8$ people, second group); ANCA participants involved local herders $(\mathrm{n}=10$ people, first group) and Yarchagumnba collectors ( $\mathrm{n}=12$ people, second group). Focus group discussions involved asking a set of questions relating to the participants' knowledge of pikas, perception towards pikas, any local folk stories about pikas, cultural and economic value of pikas, threats to pikas, and conservation of pikas. Questions were written in Nepali Language and further translated by the local Tamang people to ensure understanding by the people in LNP. All individuals participating in the focal group discussions did so via informed consent. They were informed about the nature and purpose of the group discussions to prior to the start and voluntarily agreed to participate.

\section{RESULTS AND DISCUSSION}

Based on the collective data from our investigation, three general themes relating to human-pika interaction emerged (and are detailed below); these include: the perception of pikas as a respected entity; effects of anthropogenic pollution on pikas resulting from increasing human presence, and pikas as a natural resource for use as a traditional medicine. It should be noted that statements on Buddhism, rituals, medicinal uses and belief are based solely on information provided by FGDs. Interestingly, there were notable site-specific differences with regard to the perception of and use of pikas (Table 1).

Table 1. Summary of main findings relating to human-pika interaction in Lamtang National Park Api and Nampa Conservation Area, Nepal

\begin{tabular}{|c|c|c|}
\hline \multirow{2}{*}{ Summary topics } & \multicolumn{2}{|c|}{ Protected Area (PA) } \\
\hline & Lamtang National Park & Api Nampa Conservation Area \\
\hline Demographic information & & \\
\hline People live inside the PA & Yes $(\sim 4,500)^{*}$ & Yes $(\sim 69,600)^{*}$ \\
\hline Popul. increasing inside the PA & Yes $(2.4 \% / y r)$ & Yes $(0.9 \% \mathrm{yr})^{*}$ \\
\hline Presence of security personnel inside PA & Yes & No \\
\hline Predominate religion & Buddhism & Hinduism \\
\hline Pikas as respected/protected entities & Yes & No \\
\hline Anthropogenic pollution & Yes & Yes \\
\hline Use of pikas as traditional medicine & No & Yes \\
\hline
\end{tabular}




\section{Pikas as a respected entity}

In Lamtang National Park, there are human settlements and hotels dispersed throughout the pika habitat, including in Langtang Valley, Kyanjing, Chamki, Thadepati, Laurebina and Gosainkunda. Locally, the pika is known as "Bhragomjin" and respected as a Buddhist monk (Lama) since the pika's muse resembles the meditation of a monk. The local residents reported, and we observed on a number of occasions, pikas entering homes and hotels and stealing scrapes of food and vegetables. The local people are not bothered by this behavior, instead, they welcome the intrusion as a way to show respect to the pika as a 'Lama.' This is different from the Tibetan plateau, where they talk about pikas as a hungry ghost (Yeh and Gaerrang 2021).

Culturally, Lamas in the Tamang community are priest and scholars of high rank (Holmberg 1980; Tamang 2003; Thokar 2008) who can control the rain, snow, and storms in high mountains. So, the local people believe that teasing or killing a pika is a sin and could bring unwanted rain, hail storms, thunder and destruction in their area. Even though Buddhists in Lamtang eat meat, their religious teachings mandate they do not kill any animal. They are allowed to eat the meat which was killed by others (Kwon and Tamang 2015). They not only eat meat, but also serve the meat of yak, sheep and other animals to guests. The Buddhist in South of Himalaya do not considerate it as sin to consume the meat of animals which were not killed by them (Mumford 1989). Pikas are non-hibernating mammals that spend much of the summer months storing hay in their burrows as a food source during the harsh winter. The people from Lamtang emphasized that this behavior illustrates good skill and survival knowledge that serves as a model for the people who live in the mountains. They believe it is a lesson taught by the 'Lama/pika' to the people to help them survive the harsh winter. Therefore, any damage to their crops or other food caused by pikas is ignored and accepted.

\section{Anthropogenic pollution from increasing human presence}

There is increasing human presence in LNP, both from a growing local population living within the park boundary, increasing numbers of tourists visiting the park, and annual pilgrimages. A direct result of this increase in human activity, as noted by the local people as well as from our own observations, is an increase in anthropogenic pollution (i.e., trash, and in some locations, human waste).

Tourism (trekking) represents a major source of economic growth in LNP. Annually, more than 4,000 foreign tourists visit the park. To accommodate tourist demands, local hotel owners bring large amounts of commercial food items (e.g., packets of noodles, candy bars, bottles/jars of condiments such as jams, honey, ketchup, mustard, etc.) and beverages (cans and bottles of soda, beer and alcohol) up the mountain. While the staples of the local people (e.g., rice, dahl, flour, vegetables,) entails relatively little waste, the packaging from the tourist-related items generates considerable trash and is often disposed of by dumping in off-trail areas not easily accessible or visible. The accumulating trash in these dumping areas may present potential risk to the pikas over the long term (Figure 4)

Gosainkunda Lake in LNP at 4,380 masl is a popular Ramsar site. This location also provides excellent habitat for pikas. Annually, thousands of pilgrims, including both Buddhists and Hindus, visit this area in April and again in August for religious events (Figure 3). The several-day visit involves a ritual of taking a holy bath in the lake and the practice of discarding clothing and other belonging around lake after the bath According to the local people, this practice has continued from ancient times.

During this pilgrimage, with thousands of people occupying a small area over a few days, the accumulation of clothing and trash (e.g., plastic bags, bottles, etc.) was excessive and had a direct effect on the pikas' behavior. We recorded 12 pikas that were blocked from entering (and potentially some who could not exit) their burrows due to the buildup of trash at the mouth of their burrows (Figure 4 ), additional cases were observed but not recorded as part of the study. This situation clearly increases pikas' the potential risk of predation. Additionally, we observed two pikas repeatedly removing pieces of plastic from their around their burrows. Presumably, this was being done to clean the trash from the opening of their burrows. It was unclear if the pikas ever chewed on/consumed the plastics from around burrows.

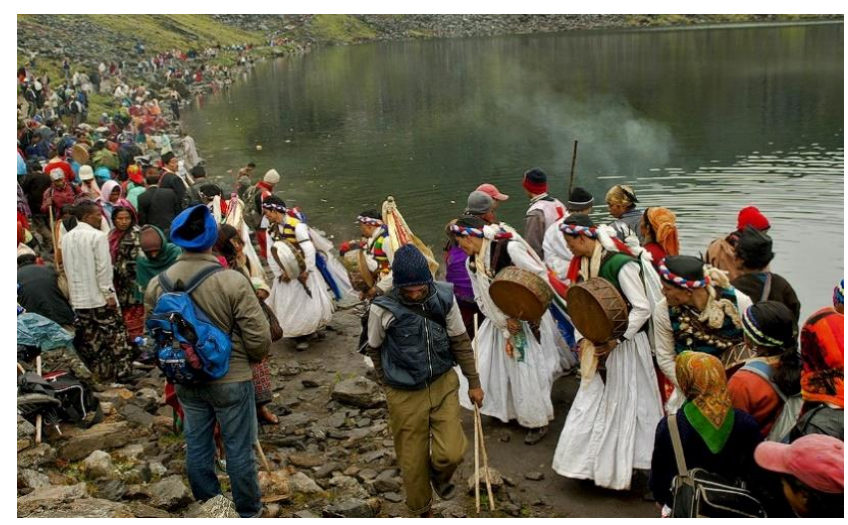

Figure 3. Pilgrims visiting Gosainkunda Lake in Lamtang National Park, Nepal (Photo by: BRK Journey, August 2016)

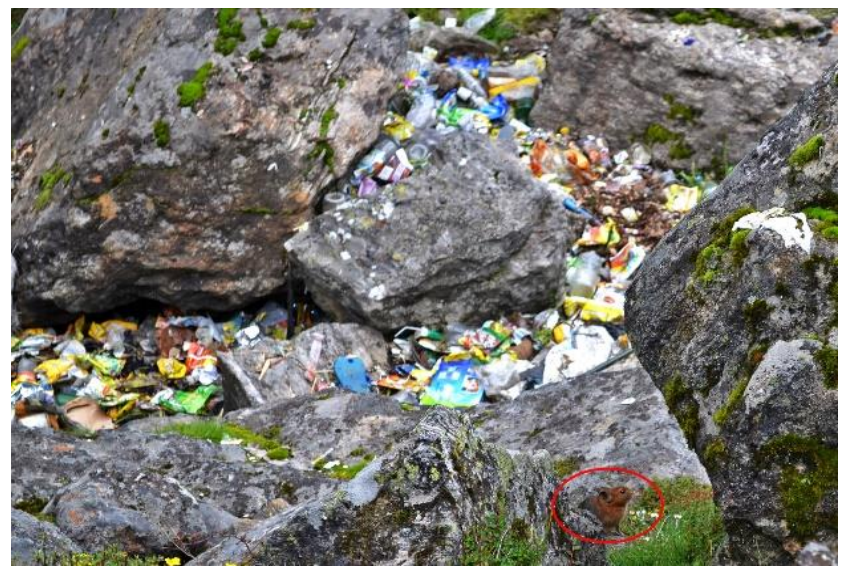

Figure 4. Accumulating trash in the habitat of Royle's pika (Ochotona roylii) habitat in the Gosainkunda Lake area of Lamtang National Park, Nepal (Photo by: N.P. Koju, July, 2013) 
In ANCA, the local people call pikas 'Hundra' or 'Khar Musa" in their language. Annually, tens of thousands of people, including local residents and those from neighboring districts of Nepal, travel to the lower slopes of Mt. Api to collect Yarsagumba $(O$. sinesis) and other valuable herbs. Approximately $860 \mathrm{~kg}$ of Yarsagumba is collected annually (ACNA 2014). During this two and half month collection period (Apr to mid-Jun) the people set up their massive tent camps throughout the pika habitat (Figure 5).

The result of this annual influx of people for an extended period was the incredible amount of trash (e.g., paper, cans, plastics, clothing) discarded in the environment when they left. We observed trash remaining throughout the area during one of our trips in October. Additionally, and potentially more concerning as a health risk for both pikas and the people, was the volume of human waste (urine and feces) that was openly dumped in the pasture land and nearby forest area on a daily basis.

\section{Pikas as traditional medicine}

In ACNA some of the herders and Yarsagumba collectors hunted pikas and dried them for traditional medicine. We observed at least 15 temporary tent huts serving as drying stations for pika meat. Dried meat of pikas was hanging at the corner of the tents (Figure 6). People used a catapult or traditional box trap to capture the pikas. The Yarsagumba collectors reported that they only capture one or two pikas in a season. The dead pika was then exposed to fire to remove the fur and hung in the tent to dry. The final process involved drying the meat in sunlight before using it as medicine (Figure 6). The people did not consume pikas as source of protein or bush meat but only as traditional medicine. The local belief is that a piece of pika meat is sufficient for curing diarrhea, asthma, joint pain and helps the body stay warm during harsh, cold conditions. Reports from the Yarsagumba collectors and local herders during the focus group discussions suggested that the local people have a long history of using the pika as a traditional medicine.

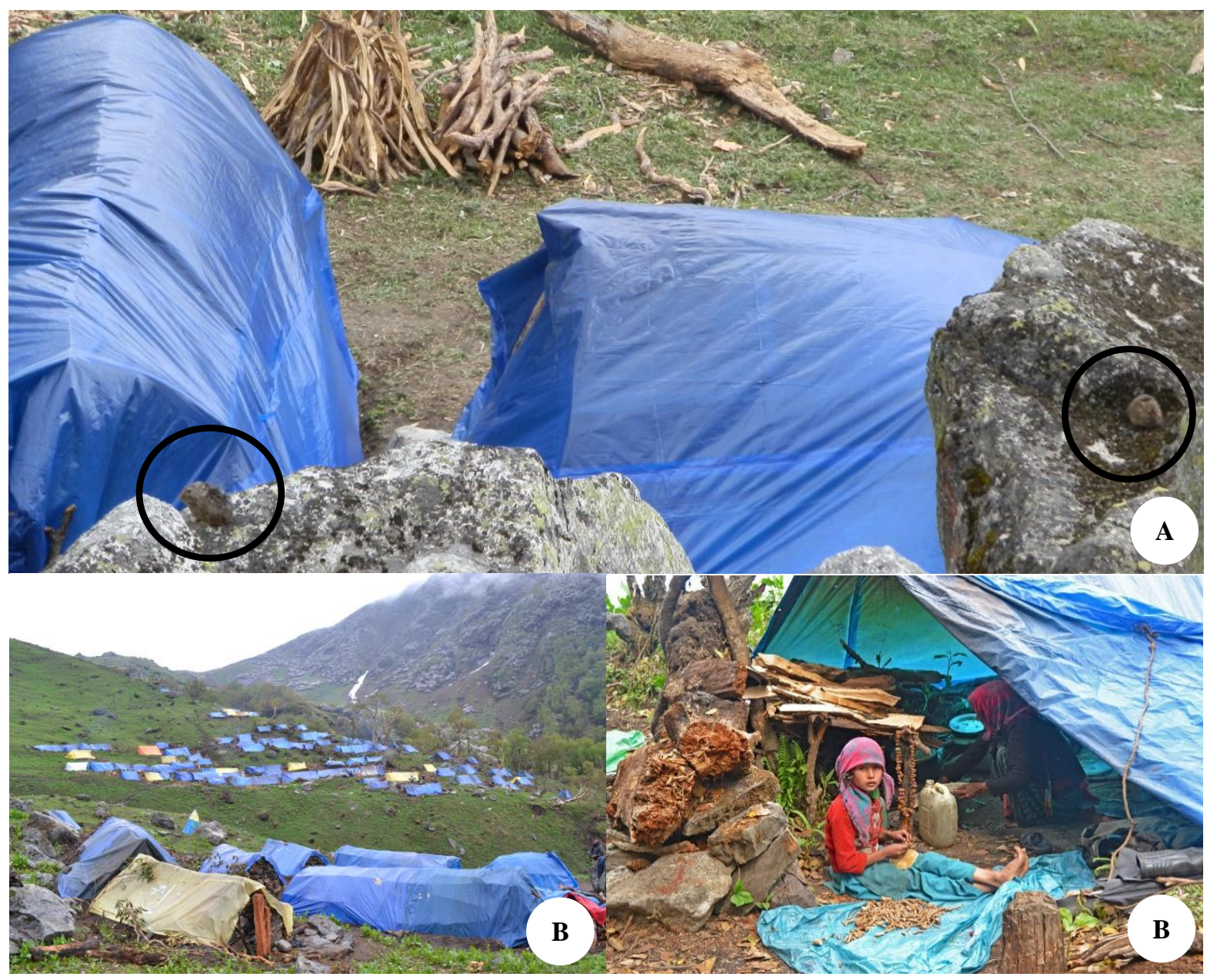

Figure 5. A-B. Temporary tent camps set up in pika habitat (3,500 m asl.) in the Api Nampa Conservation Area, Nepal during collection of Yarsagumba (Ophiocordyceps sinesis) and other valuable herbs (Photo by: N.P. Koju, June 2013). C. A girl with medicinal herbs collected in Api Nampa Conservation Area (Photo by: N.P. Koju, June 2013) 

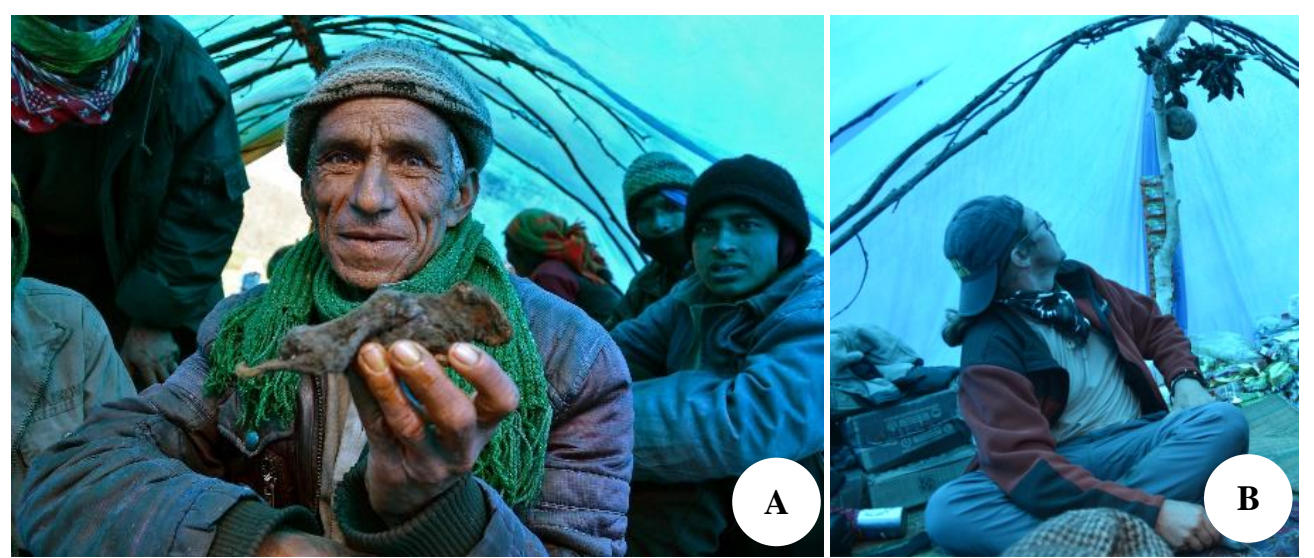

Figure 6. A. Local man holding a pika dried in sunlight for use as a traditional medicine. B. Dried animal meat including that of pikas hanging in a tent in Api Namapa Conservation Area. (Photo by: N.P. Koju, June, 2013)

\section{Discussion}

This study represents one of the first attempts to examine human-pika interaction in Nepal. As such, this work provides important baseline data upon which to base a more thorough examination of human-pika interaction and conduct a quantitative assessment of the anthropogenic impact on the pika populations and its long-term survival.

The results of our study demonstrate that religion, along with cultural/indigenous beliefs can contribute to a tolerance, even protection, of pikas in certain areas of Nepal. Specifically, in LNP, where the predominate religion is Buddhism, the local people were consistent in their reports of acceptance and respect for the pika, a finding that we also observed from their behavior. Conversely, in the ANCA, where Hinduism is the predominate religion, the pika was seen as a resource that could be used for human benefit such as traditional medicine.

Although the cultural beliefs and practices in LNP that promote respect for the pikas as monks help with the conservation of pikas and protect them from killing and hunting, the anthropogenic pollution caused by cultural rituals and tourism is posing a potential risk to the pikas' survival. The effects that the trash may be having on the pikas, as well as other wildlife, needs further study.

The final major finding of our study involved the use of pikas as a traditional medicine by the local people in ANCA. The people believe that the pikas' ability to consume and digest poisonous plants makes them valuable for medicinal use, particularly for treatment of diarrhea, asthma, and joint pain. Of course, such a claim requires further biomedical and biochemical analysis.

Globally, wildlife products are used for consumption or display, and in many cultures are considered to have high medicinal and spiritual value (Scoones et al. 1992; van Uhm 2018). Interestingly, pikas also have a varied history of traditional uses in other parts of the world. Pikas were valued for their fur in the Soviet Union prior to World War II as their fur was used to produce high quality felt (Smith et al. 1990). In Yakutia, the trapping of northern pika $O$. hyperborea yesoensis for food was a frequent activity until 1953 (Tavrovski et al. 1971). Similarly, in Kazakh SSR (formerly USSR), pikas were trapped until the 1950s for food (Sludski et al. 1982; Smith et al. 1990), and it is reported that the local people in Mt. Gaolingong in Yunnan, China also consumed pika (O. forresti) (personal communication with $\mathrm{Li}$ Quan Kunming institute of Zoology). Further, soft feces of pika have been used as a folk medicine in central Asia (Smith et al. 1990). Therefore, it is not surprising that we observed the use of pikas as a traditional medicine by the local people in ANCA.

As we are well aware, Nepal is a country where the dependence on wildlife for food and traditional medicine is directly related to the economic status of marginalized people. Can pikas serve as an alternative source of food or as traditional medicine for people living in the remote areas who cannot afford the cost and time to see a doctor of modern medicine in the cities? Are pieces of meat from a small alpine mammal really effective in curing disease, or is this practice simply based on belief or myth without scientific merit? These are important questions that we hope to explore in more detail in the near future.

In conclusion, interaction between humans and pikas is continuing from ancient time in Himalayas of Nepal. Pikas in central Himalaya is respected as monk by Buddhist community and are consumed by local people in western Himalaya as traditional medicine. Human interference and anthropogenic pollution is threat to pikas survival in both protected areas. Protected areas and leaders of religious group should take initiation to reduce the pollution cause by the rituals and practices. The support and collaboration between all stakeholders necessary to conserve wildlife and its habitat. Further scientific research is warranted for medical use of pikas and its interaction with human for pikas conservation in future.

\section{ACKNOWLEDGEMENTS}

We would like to thank local people from Lamtang National Park and Api Nampa Conservation, Nepal area for their kind cooperation during the field work. We thank the Department of National Park and Wildlife Conservation, 
Lamtang National Park, and Api Nampa Conservation Area for providing permission and approval to conduct this study. The study was partially supported by a "Fresh Graduate Ph.D. Fellowship" from the University Grant Commission of Nepal to NPK. RCK's effort was supported in part by the Office of Research Infrastructure Programs (ORIP) of the National Institutes of Health through Grant Number P51OD010425 to the WaNPRC.

\section{REFERENCES}

Abe H. 1971. Ecological distribution and faunal structure of small mammals in central Nepal. Mammalia 46 (4): 477-504. DOI: 10.1515/mamm.1982.46.4.477.

ACNA. 2014. Internal Report. Api Nampa Conservation Area, Nepal.

Beever EA, Ray C, Wilkening JL, Brussard PF, Mote PW. 2011. Contemporary climate change alters the pace and drivers of extinction. Glob Change Biol 17 (6): 2054-2070. DOI 10.1111/j.1365-2486.2010.02389.x.

Bhattacharyya S, Adhikari BISA, Rawat GS. 2013. Forage selection by Royle's pika (Ochotona roylei) in the western Himalaya, India. Zoology 116 (5): 300-306. DOI: 10.1016/j.zool.2013.05.003.

Bista DB.1972. Sabai Jatko Fulbari. Sajha Prakashan, Kathmandu.

Cadwalladr C.2015. Nepal Earthquake: The Village Wiped Off the Map in a Few Terrifying Seconds. Theguardian.

CBS. 2011. National Population and Housing Census 2011. Central Bureau of Statistics, Nepal.

Chapagain PS. 2015. Tourism development and energy consumption pattern in Langtang valley of Nepal Himalayas. J Dev Adm Stud 23 (1-2): 69-83. DOI: 10.3126/jodas.v23i1-2.15449.

DNPWC. 2020. Protected Areas of Nepal. Retrieved April 20, 2021 Retrieved from https://dnpwc.gov.np/en/.

Ellerman JR, Morrison-Scott TCS. 1951. Checklist of Palaearctic and Indian Mammals, 1758 to 1946. Order of the Trustees of the British Museum, UK.

Fedosenko AK. 1974. Some morphological characteristics of Ochotona Zoology 53:485-486.

Formozov NA. 1981. Behavioural adaptations of pikas in rocky biotopics. In: Naumov NP (eds.). Ecology, Population, Structure and Communication Processes in Mammals. Nauka, Moscow.

Giri H. 2020. An exploration of ethnic dynamics in Nepal. Popul Dev 1 (1): 71-78. DOI: 10.3126/jpd.v1i1.33106.

Holmberg DH. 1980. Lama, Shaman, and Lambu in Tamang Religious Practice. Cornell University, Ithaca, NY.

Jnawali SR, Baral HS, Lee S, Acharya KP, Upadhyay GP, Pandey M, Shrestha R, Joshi D, Laminchhane BR, Griiths J, Khatiwada AP Subedi N, Amin R. 2011. The Status of Nepal's Mammals: The National Red List Series. Department of National Parks and Wildlife Conservation, Nepal. DOI:10.13140/RG.2.1.2561.7448.

Karki R, Kandel K, Kunwar A, Bhatta J, Thapa P, Panthi S, Pant PK. 2020. Yarsagumba collection and marketing: A key income source of people in Api Nampa Conservation Area, Darchula, Nepal. J Agric Nat Resour 3 (1): 219-232. DOI: 10.3126/janr.v3i1.27175

Kawamichi T. 1968. Winter behaviour of the Himalayan Pika (Ochotona roylei). Jour Fac Sci Hokkaido Univ Ser 6 (16): 582-554.

Kawamichi T. 1971. Daily activities and social pattern of two Himalayan Pikas, Ochotona macrotis and $O$. roylei, observed at Mt. Everest. J Fac Sci Hokkaido Univ Ser VI Zool 17 (4): 587-609.

Koju N, Chalise M, Kyes R. 2021. Acute cold stress: A potential threat to Royle's pika (Ochotona roylii) survival at Central Himalayas of Nepal. Banko Janakari 31 (1): 33-40. DOI: 10.3126/banko.v31i1.37343

Koju NP, Chalise MK. 2013. Royle's pika (Ochotona roylei) observation in Api Nampa Conservation Area, Nepal. J Nat Hist Mus Nepal 27: 78-86. DOI: 10.3126/jnhm.v27i0.14156.

Koju NP, Chalise MK, Kyes RC. 2012. Seasonal survey of Large ear pika (Ochotona macrotis) at Langtang Natonal Park, Nepal. J Univ Grants Commiss 1: 74-82.

Koju NP, Chalise MK, Kyes RC. 2013. Forage selection and conservation threats on pika (Ochotona species) at Gosainkunda area, Langtang National Park. Wildlife Week 18: 33-41.
Koju NP, Chalise MK, XueLong J. 2015. Population abundance of Royle's pikas (Ochotona roylei) along altitudinal gradients in Langtang National Park, Nepal. South-Asian J Multidiscip Stud 2 (1): 1-6.

Koju NP, He K, Chalise MK, Ray C, Chen Z, Zhang B, Wan T, Chen S, Jiang X. 2017. Multilocus approaches reveal underestimated species diversity and inter-specific gene flow in pikas (Ochotona) from southwestern China. Mol Phylogenet Evol 107: 239-245 DOI: 10.1016/j.ympev.2016.11.005.

Kwon DY, Tamang JP. 2015. Religious ethnic foods. J Ethnobiol Foods 2 (2): 45-46. DOI: 10.1016/j.jef.2015.05.001

Lissovsky AA, Yatsentyuk SP, Koju NP. 2019. Multilocus phylogeny and taxonomy of pikas of the subgenus Ochotona (Lagomorpha, Ochotonidae). Zoologica Scripta 48 (1): 1-16. DOI: 10.1111/zsc.12325.

Mack N, Woodsong C, MacQueen KM, Guest G, Namey E. 2005. Qualitative Research Methods: A Data Collector's Field Guide. Family Health Internasional, North Carolina, USA.

Ministry of Local Development 2017. Distribution of local government (in Nepali). Retrieved October 20, 2020, Retrieved from https://sthaniya.gov.np/gis/.

Mishra PN. 2011. The Langtang National Park: A proposed first biosphere reserve in Nepal. J Natl Sci Found 31 (1-2): 333-335. DOI: 10.4038/jnsfsr.v31i1-2.3045.

Mullin MH. 1999. Mirrors and windows: Sociocultural studies of humananimal relationships. Ann Rev Anthropol 28 (1): 201-224. DOI: 10.1146/annurev.anthro.28.1.201

Mumford S. 1989. Himalayan Dialogue: Tibetan Lamas and Gurung Shamans in Nepal. Univ of Wisconsin Press, Madison, WI

Phair NL, Toonen RJ, Knapp ISS, von der Heyden S. 2020. Anthropogenic pressures negatively impact genomic diversity of the vulnerable seagrass Zostera capensis. J Environ Manag 255: 109831. DOI: 10.1016/j.jenvman.2019.109831.

Scoones I, Melnyk M, Pretty JN. 1992. The Hidden Harvest: Wild Foods and Agricultural Systems. A Literature Review and Annotated Bibliography. International Institute of Environment and Development, London. https://pubs.iied.org/6006iied.

Shanklin E. 1985. Sustenance and symbol: Anthropological studies of domesticated animals. Ann Rev Anthropol 14: 375-403. DOI: 10.1146/annurev.an.14.100185.002111.

Sing NB, Khanal D, Bhandari L. 2020. Yarsagumba collection trend and its impact on livelihood of people of Bajhang District in the context of climate change. Geograph Base 7: 65-78. DOI: 10.3126/tgb.v7i0.34272.

Sludski AA, Afanasiev YG, Bekenov A, Grachev YA, Lobachev YS, Makhmutov S, Strautman EI, Fedosenko AK, Shubin. 1982. Mammals of Kazakhstan. Nauka, Alma Ata, Kazakh SSR.

Smith AT. 2020. Conservation status of American pikas (Ochotona princeps). J Mammal 101 (6): 1466-1488. DOI: 10.1093/jmammal/gyaa110.

Smith AT, Formozov N, Hoffmann RS, Changlin Z, Erbajena MA. 1990. The pikas. In: Chapman JA, Flux JEC (eds.). The Pika Accounts of Genera and Species, Rabbits, Hares and Pikas. Status Survey and Conservation Action Plan. IUCN/SSC Lagomorph Specialist Group IUCN, Gland, Switzerland.

Stevens S. 2014. Indigenous Peoples, National Parks, and Protected Areas: A New Paradigm Linking Conservation, Culture, and Rights. University of Arizona Press, Tucson, AR.

Stevens SF. 1996. Claiming the High Ground: Sherpas, Subsistence, and Environmental Change in the Highest Himalaya. Motilal Banarsidass Publisher, New Delhi.

Tak PC, Lamba BS. 1985. Nanda Devi National Park: A contribution to its mammalogy. Indian J For 8: 219-230.

Tamang G. 2003. An ethnobiological study of the Tamang people. Our Nature 1 (1): 37-41. DOI: 10.3126/on.v1i1.303

Thapa A, Dahal B, Koju N, Thapa S. 2011. A Review on Pikas of Nepal. Small Mammals Conservation and Research Foundation, New Baneshwor, Kathmandu, Nepal.

Tavrovski VA, Yegorov OV, Krivosheyev VG, Popov MV, Labutin YV. 1971. Mammals of Yakutia. "Nauka," Moscow.

Thokar R. 2008. Tamang: A sociolinguistic scenario. Nepalese Linguist 23: 391-407.

van Uhm DP. 2018. The social construction of the value of wildlife: A green cultural criminological perspective. Theor Criminol 22 (3): 384-401. DOI: 10.1177/1362480618787170.

Yeh ET, Gaerrang 2021. Pests, keystone species, and hungry ghosts: The Gesar epic and human-pika relations on the Tibetan Plateau. Cult Geogr 28 (3): 461-478. DOI: 10.1177/1474474020963144. 